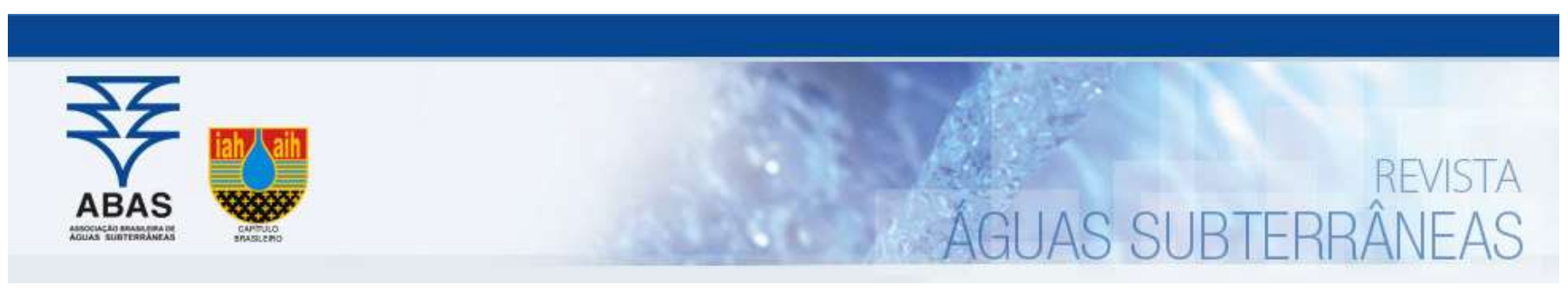

Estudos de Caso e Notas Técnicas

\title{
Physico-chemical quality of waters of tubular wells located in the interior of the State of Rio Grande do Norte
}

\section{Qualidade físico-química de águas de poços tubulares localizados no interior do Estado de Rio Grande do Norte}

\section{Gerbeson Carlos Batista Dantas; Henriqueta Monalisa Farias²; Camila Rafaela Santos de Oliveira2; Arthuro Munay Dantas da Silveira1; Sâmea Valensca Alves Barros ${ }^{1 凶}$}

1 Universidade Federal Rural do Semi-Árido (UFERSA), Angicos, RN

2 Universidade Federal de Campina Grande (UFCG), Sumé, PB

\gerbeson_dantas@hotmail.com, monalisa_miller@hotmail.com, camis_rafaela@hotmail.com, arthuromds@hotmail.com, sameavalensca@ufersa.edu.br

Keywords:

Potability Ordinance.

Physico-chemical Parameters.

Water Quality.

Tubular Wells.

\section{Abstract}

This work aims to perform the physical-chemical characterization of the water of two tubular wells, in the period of three months, located in the rural area of the municipality of Parelhas, State of Rio Grande do Norte, and later, analyze the viability of use of the raw water for consumption human. In order to characterize them, 15 parameters were determined for both sample $A$ and sample $\mathrm{B}: \mathrm{pH}$, electrical conductivity, source temperature, bicarbonate (HCO3-), chloride (Cl-), Total Hardness (CaCO3), hardness (Ca2+), hardness (Mg2+), alkalinity, dissolved total solids, dissolved oxygen, ammoniacal nitrogen, nitrite (NO2-), nitrate (NO3-) and iron. According to the tests, the waters under analysis presented disagreements in relation to the Potability Ordinance 2914/2011 in the following parameters: Alkalinity, total dissolved solids, nitrates, nitrites and iron. In addition, the waters were classified as hard (sample B) and very hard (sample A), presented extremely high conductivity, high to $590 \mu \mathrm{S} . \mathrm{cm}-1$ and low dissolved oxygen content. Finally, this study concludes from the results of the physical-chemical parameters of sample A and sample B that the gross water from the wells is inappropriate for human consumption.

Resumo

Este trabalho tem como objetivo realizar a caracterização físico-química da água de dois poços tubulares, no período de três meses, localizados na zona rural do município de Parelhas, Estado do Rio Grande do Norte, e posteriormente, analisar a viabilidade de utilização da água bruta para consumo humano. Em relação às analises físico-químicas, foram determinados 15 parâmetros, tanto para a amostra A, como para a amostra B, a fim de caracterizá-las: $\mathrm{pH}$, condutividade elétrica, temperatura na fonte, bicarbonato $\left(\mathrm{HCO}^{3-}\right)$, cloreto $(\mathrm{Cl})$, dureza total $\left(\mathrm{CaCO}_{3}\right)$, dureza $\left(\mathrm{Ca}^{2+}\right)$, dureza $\left(\mathrm{Mg}^{2+}\right)$, alcalinidade, sólidos totais dissolvidos, oxigênio dissolvido, nitrogênio amoniacal, nitrito ( $\mathrm{NO}^{2-}$ ), nitrato (NO3-) e ferro. De acordo com os ensaios, as águas sob análise, apresentaram discordâncias em relação a Portaria de Potabilidade 2914/2011 nos seguintes parâmetros: Alcalinidade, sólidos totais dissolvidos, nitratos, nitritos e ferro. Somando-se a isso, as águas foram classificadas como duras (amostra B) e muito duras (amostra A), apresentaram condutividade extremamente elevada, superior a $590 \mu \mathrm{S} . \mathrm{cm}^{-1}$ e baixo teor de oxigênio dissolvido. Por fim, este trabalho conclui, a partir dos resultados dos parâmetros físico-químicos da amostra $\mathrm{A}$ e amostra B, que as água brutas dos poços estão inapropriadas ao consumo humano.

DOI: http://dx.doi.org/10.14295/ras.v32i1.29098

\section{INTRODUCTION}

Water is an essential resource for human survival due to its wide applicability in the most varied anthropic activities and therefore it is directly interconnected to economic development, social wellbeing, health and environmental quality. Although abundant in relation to the quantitative aspect, there are restrictions on its use due to qualitative aspects, both for human consumption, as well as for animal, industrial, agricultural and other adjacent activities. In this perspective, with the formation of urban conglomerates and densification of industrial activities, especially after the Industrial Revolution, water, in the dynamics of quantitative and qualitative availability, has become a strong adversity for contemporary societies, both for the demand for use, by the contamination of water bodies by domestic and, above all, industrial effluents, and may even be a scarce resource. The authors Alves and collaborators (2012) agree with this view when affirming that the deterioration of water quality can be caused both by the result of anthropic pressures on aquatic environments, on a larger scale, and by natural factors, 
on a smaller scale. Pereira (2004) states that anthropic activities generate characteristic pollutants that have a certain implication in the quality of the receiving body.

The growth and development of modern societies depend on the supply of water that meets drinking standards. The standards of potability are related to physical-chemical attributes, such as $\mathrm{pH}$, electrical conductivity, presence of chlorides, iron, nitrates, nitrites, ammoniacal nitrogen, presence of magnesium and calcium, personified in hardness, alkalinity and so on. In addition to the physical-chemical attributes, there is an incursion of microbiological parameters, such as the presence of total coliforms, thermotolerant and fecal, personified in the presence of pathogenic etiological agents such as Escherichia coli, Cysts of giardia and Cryptosporidium oocysts.

In this sense, studying the physical, chemical, microbiological characteristics of water, as well as continuously monitoring the quality of human water supply is translated into a beneficial practice for people's health, as water is a potential vehicle for diseases and has historically been, responsible for numerous pests to ancestral societies (LIBÂNIO, 2016). In this way it is necessary to observe the factors that can negatively interfere in its quality avoiding rejection by the people, diseases and disorders conveyed by the quality of the water.

As for the distribution of water in Brazil is quite uneven. More specifically, northeastern region has faced numerous are proven due to the problems caused by the low precipitation rates, the long periods of drought and, in addition, the arid climate characterized by high temperatures and solar incidence, and therefore it is fundamental to develop alternatives, environmentally sound management of existing water resources. One of the most important alternatives is the use of groundwater, as this water reserve resists throughout the dry season (MOURA et al., 2016).

The importance of groundwater abstraction is dated, in Northeast Brazil, many decades ago. According to Pereira (2008), until the end of the 1990, riparian communities in the semi-arid region of Paraiba obtained water only through Amazonian wells and cacimbas located on river banks for irrigation, animal feed and human consumption. Another important source currently developed in several rural communities is cisterns. This system installed through the implementation of government programs, such as the federal government's one million cisterns program (P1MC), is intended to store water during the rainy season to meet dry season needs. However, with the recent deepening of drought periods, the water stored by the cisterns becomes insufficient, and the underground waters are gaining a vertiginous importance, especially with the drilling of the artesian wells, covering the deeper layers of the soil and, therefore, in greater quantity.

In view of this perspective, the National Congress, in compliance with the demands, promulgated Law n. 9433/1997, establishing the National Policy on Water Resources (NPWR), of the central importance of the use of groundwater in the Brazilian Northeast.
The NPWR guides the management of water bodies throughout the Brazilian territory, determining the criteria, instruments, and guidelines for water resource management. Among the actions, is the creation of the National System of Management of Water Resources (NSMWR), aiming to regulate the use and management of the waters of the hydrographic basins (BRAZIL, 1997). Another important instrument is the Water Potability Ordinance, valid under the terms of Ordinance 2914 of 2011. This Ordinance has provisions on the control procedures, monitoring of water quality and above all, it brings the patterns of potability to the physical attributes, chemical and microbiological characteristics of water for human consumption (BRAZIL, 2011).

In this context and knowing that in Brazil, it is estimated that 30 to $40 \%$ of the population uses groundwater as source of supply (HIRATA; ZOBY; OLIVEIRA, 2010; PACHECO et al., 2016). The objective of this work is to perform the physico-chemical characterization of the water of two tubular wells, in the period of three months, located in the municipality of Parelhas, State of Rio Grande do Norte, and later, analyze the viability of use of the raw water for consumption human.

\section{METHODOLOGY}

\subsection{Study area}

The study area is centered on two wells (samples A and B) located in the rural area of the municipality of Parelhas, State of Rio Grande do Norte. The municipality of Parelhas has a territorial area of $513.5 \mathrm{~km}^{2}$ and population estimated at 21,669 population (IBGE, 2010).

\subsection{Collection and Experimental Procedure}

The collections were carried out in three stages: the first on May 11 (first collect), the second on June 11 (second collect) e and 11 of July (third collect) both in the year 2016. The analyzes were done in triplicate and extracted the simple arithmetic means. To characterize as samples the following parameters were tested: $\mathrm{pH}$, electrical conductivity, temperature at source, bicarbonate $\left(\mathrm{HCO}^{3}\right)$, chloride $\left(\mathrm{Cl}^{-}\right)$, nitrate $\left(\mathrm{NO}^{3}-\right)$, total Hardness $\left(\mathrm{CaCO}_{3}\right)$, hardness $\left(\mathrm{Ca}^{2+}\right)$, hardness $\left(\mathrm{Mg}^{2+}\right)$, alkalinity, total dissolved solids (TDS), dissolved oxygen (DO), ammoniacal nitrogen, nitrite ( $\mathrm{NO}^{2-}$ ) and iron.

The techniques used in collecting the samples and determining physical and chemical attributes are described in the Standard Methods Manual (APHA, 2005) and carried out by other works (CAPP et al., 2012; MENEZES et al., 2013; PACHECO et al., 2016; ALSUHAIMI; ALMOHAIMIDI; MOMANI, 2017).

\section{RESULTS AND DISCUSSION}

The physical-chemical parameters of the water samples from the first, second e third samples are presented in Table 1. The samples were evaluated under the aegis of the standards of Potability Ordinance $n^{\circ}$ 2914/2011 (Table 2) (BRAZIL, 2011). 
Table 1 - Physical-chemical analysis of wells A and B in the two collection

\begin{tabular}{|c|c|c|c|c|c|c|}
\hline \multirow[b]{2}{*}{ Parameters } & \multicolumn{3}{|c|}{ Sample A } & \multicolumn{3}{|c|}{ Sample B } \\
\hline & $\begin{array}{c}\text { First } \\
\text { collect }\end{array}$ & $\begin{array}{l}\text { Second } \\
\text { collect }\end{array}$ & $\begin{array}{l}\text { Third } \\
\text { collect }\end{array}$ & $\begin{array}{c}\text { First } \\
\text { collect }\end{array}$ & $\begin{array}{l}\text { Second } \\
\text { collect }\end{array}$ & $\begin{array}{l}\text { Third } \\
\text { collect }\end{array}$ \\
\hline Conductivity $(\mu \mathrm{S} / \mathrm{cm})$ & 1360 & 1400 & 1450 & 620 & 600 & 590 \\
\hline $\mathrm{pH}$ & 8.02 & 7.78 & 7.24 & 8.30 & 8.00 & 7.40 \\
\hline Temperature $\left({ }^{\circ} \mathrm{C}\right)$ & 25 & 23 & 21 & 28.00 & 21.00 & 20.00 \\
\hline Chloride (mg/L) & 258.70 & 221.10 & 209.10 & 53.18 & 12.00 & 7.09 \\
\hline $\begin{array}{l}\text { Total Hardness }\left(\mathrm{CaCO}_{3}\right) \\
\qquad(\mathrm{mg} / \mathrm{L})\end{array}$ & 302.50 & 338.50 & 355.00 & 175.00 & 170.00 & 167.5 \\
\hline Hardness $\mathrm{Ca}^{2+}(\mathrm{mg} / \mathrm{L})$ & 147.50 & 149.00 & 150.00 & 97.50 & 90.00 & 77.50 \\
\hline Hardness Mg2 + (mg L) & 155.00 & 189.00 & 205.00 & 77.00 & 80.00 & 90.00 \\
\hline Alkalinity (mg/L) & 984.00 & 1001.10 & 1096.00 & 566.00 & 566.00 & 564.00 \\
\hline Bicarbonates (mg/L) & 984.00 & 1001.10 & 1096.00 & 566.00 & 566.00 & 564.00 \\
\hline $\begin{array}{l}\text { Total Dissolved Solids } \\
\qquad(\mathrm{mg} / \mathrm{L})\end{array}$ & 821.00 & 852.00 & 872.00 & 396.00 & 394.00 & 391.00 \\
\hline $\begin{array}{l}\text { Dissolved Oxygen (mg } \\
\left.\qquad \mathrm{O}_{2} / \mathrm{L}\right)\end{array}$ & 2.00 & 1.97 & 1.93 & 1.60 & 1.55 & 1.53 \\
\hline $\begin{array}{c}\text { Ammoniacal nitrogen } \\
(\mathrm{mg} / \mathrm{L})\end{array}$ & 0.00 & 0.00 & 0.00 & 0.00 & 0.00 & 0.00 \\
\hline Nitrate (mg/L) & 14.97 & 11.12 & 10.37 & 14.30 & 13.12 & 12.50 \\
\hline Nitrite (mg/L) & 1.11 & 1.06 & 1.07 & 1.49 & 1.48 & 1.44 \\
\hline Iron (mg/L) & 0.42 & 0.43 & 0.43 & 0.41 & 0.41 & 0.44 \\
\hline
\end{tabular}

Table 2 - Potability standards according to the Ordinance 2914/2011

\begin{tabular}{|c|c|}
\hline Parameters & Potability Ordinance $n^{\circ}$ 2914/2011 \\
\hline Conductivity ( $\mu \mathrm{S} / \mathrm{cm})$ & - \\
\hline $\mathrm{pH}$ & $6-9.5$ \\
\hline Temperature $\left({ }^{\circ} \mathrm{C}\right)$ & $22^{\circ} \mathrm{C}$ \\
\hline Chloride (mg/L) & 250 (mg/L) \\
\hline Total Hardness $\left(\mathrm{CaCO}_{3}\right)(\mathrm{mg} / \mathrm{L})$ & $500(\mathrm{mg} / \mathrm{L})$ \\
\hline Alkalinity (mg/L) & $500(\mathrm{mg} / \mathrm{L})$ \\
\hline Total Dissolved Solids (mg/L) & $1000(\mathrm{mg} / \mathrm{L})$ \\
\hline Dissolved Oxygen (mg O2/L) & - \\
\hline Ammonia Nitrogen (mg/L) & $1.5(\mathrm{mg} / \mathrm{L})$ \\
\hline Nitrate (mg/L) & 10 (mg/L) \\
\hline Nitrite (mg/L) & $1(\mathrm{mg} / \mathrm{L})$ \\
\hline Iron (mg/L) & 0.3 (mg/L) \\
\hline
\end{tabular}

The temperature of the collected samples varied from $21^{\circ} \mathrm{C}$ to $28^{\circ} \mathrm{C}$, being $25^{\circ} \mathrm{C}$ to $21^{\circ} \mathrm{C}$ for sample $\mathrm{A}$ and $28^{\circ} \mathrm{C}$ for $20^{\circ} \mathrm{C}$ for sample B. Temperature is very important, since it influences the biological processes, chemical and biochemical reactions, as well as the solubility of the dissolved gases, conductivity and mineral salts in the water (MACEDO, 2004; DANELUZ; TESSARO, 2015). The abrupt temperature variation from the first to the second collection can be explained by the time of the day of collection, since the clouds were blocking the solar radiation, as well as the incidence of small rainfall. The author Bucci et al. (2015) agrees with this when affirming that the change in temperature may be associated with the seasons, except when the water body is contaminated by domestic or industrial effluents.

Regarding $\mathrm{pH}$, both samples presented alkaline classification, ranging from 7.24 to 8.3. According to the Potability Ordinance 2914 (BRAZIL, 2011), the values are within acceptable limits for human consumption, since they are within the range of $\mathrm{pH} 6$ and 9.5. According to Esteves (1998), waters with $\mathrm{pH}$ in this range can be explained by the small amount of organic matter to be decomposed, since for decomposition of these, many resulting acids are produced. As for the DO, a low concentration of the same was observed in the water samples, reducing between the analysis periods. As the temperature did not increase, which could volatilize the DO, there was no abrupt variation of the pressure, and the results indicate that this may have occurred due to the accumulation of nondepudate organic matter due to the low flow velocity.

The conductivity of the two samples is extremely high. Sample A showed $1360 \mu \mathrm{S} . \mathrm{cm}^{-1}$, increasing to $1450 \mu \mathrm{S} . \mathrm{cm}^{-1}$ in the third collect. Sample B, however, showed $620 \mu \mathrm{S} . \mathrm{cm}^{-1}$ and $590 \mu \mathrm{S} . \mathrm{cm}$ 1 in the first and third samples, respectively. According to Mendes and Oliveira (2004), these values are explained by the excess of water mineralization, since, for the author, values of conductivity higher than $1000 \mu \mathrm{S} . \mathrm{cm}^{-1}$ are characteristic of waters unfit for human use, especially, by the unpleasant taste. However, the water potability standards defined by Ordinance 2914 do not define adequate values of conductivity (BRAZIL, 2011).

With regard to TDSs, some important considerations. The sample B presented values of $396 \mathrm{mg} . \mathrm{L}^{-1}$ and $391 \mathrm{mg} . \mathrm{L}^{-1}$ in the first and 
third collection, respectively. These values comply with the Potability Ordinance 2914/2011, whose established limit is 1000 mg. L-1 (BRAZIL, 2011). On the other hand, samples A presented values between 821 mg.L-1 and 872 mg.L-1, falling within Ordinance 2914 (BRAZIL, 2011), but diverging from Resolution 357 (BRAZIL, 2005), whose value is 500 mg.L-1. Another important factor is that the TDS values corroborated with the conductivity. The greater the amount of dissolved solids in the water, the greater its conductivity, that is, it occurs in a directly proportional relation. In this sense, sample A presented TDS ranging from 821 mg.L-1 to 872 mg.L-1, while the conductivity also increased. In sample $B$, the conductivity decreased, while the TDS reduced from $396 \mathrm{mg} . \mathrm{L}^{-1}$ to $391 \mathrm{mg} \cdot \mathrm{L}^{-1}$.

Regarding hardness, the samples presented values ranging from $167.5 \mathrm{mg} . \mathrm{L}^{-1}$ to $360 \mathrm{mg} . \mathrm{L}^{-1}$, with $302.5 \mathrm{mg} . \mathrm{L}^{-1}$ increasing to 355 mg.L-1 for sample A and $175 \mathrm{mg.L} \mathrm{L}^{-1}$ reducing to $167.5 \mathrm{mg.L} \mathrm{L}^{-1}$ for sample $B$. Frequently the hardness is the sum of calcium and magnesium present in the water. Its contents are related to the inability to form foams in water when it interacts with surfactants, as well as cause fouling of pipe walls (RICHTER, 2009). According to the author, water can be classified as: soft ( $<50 \mathrm{mg} / \mathrm{L})$, moderately hard (50-150 mg/L); (150-300 mg/L) and very hard (>300 mg/L). Thus, sample A presented water with characteristics of very hard and therefore inappropriate for both human consumption and human cleaning activities, once the activities related to cleaning will be impaired due to $\mathrm{Ca}^{2+}$ and $\mathrm{Mg}^{2+}$ interacting with the acids, as well as, there will be a problem in the water collection pipes, since it can completely obstruct the pipe, causing disruption (RICHTER, 2009). Sample B, although it presented levels of hardness inferior to sample $A$, was classified as hard water, being able, in a certain time, to cause effects similar to the one mentioned above. The high hardness of the studied waters is explained by the rocky formation of the municipality of Parelhas, which presents a highly crystalline formation, salinizing by the contact with the rocks, the groundwater. However, Ordinance 2914/2011 establishes a limit of 500 mg.L-1 for, therefore, the samples are within this criterion (BRAZIL, 2011).

Alkalinity is a characteristic of water in neutralizing an acid, without compromising its qualitative attributes. Water is alkaline because of hydroxides, carbonates and, above all, bicarbonates. The values obtained above 564 mg.L-1 for both samples are much higher than those established by the Potability Ordinance 2914/2011, characterizing inappropriate use for human consumption (BRAZIL, 2011). In general, very high alkalinity is related to effluent contamination (POHLING, 2009).

Regarding the presence of chloride, the samples presented values between 7.09 mg. L-1 and 258.70 mg.L-1, so that sample A presented in one of the collections high concentrations which constitutes a problem for sample A from the point of view of potability, since Ordinance 2914 / 2011 establishes maximum upper limit of 250 mg.L-1 (BRAZIL, 2011). According to Pohling (2009), when the chloride content is high in water, two main reasons are: geological influence and contamination from effluents (POHLING, 2009; BARCELLOS et al., 2006; PACHECO et al., 2016). The United States Environmental Protection Agency (2015), states that chloride is an ion may have anthropogenic and geological origin, being leached from rocks, domestic and industrial sewage to its main source (USEPA, 2015). The probable contamination of effluents in the studied wells is quite high, as well as being close to areas of the residences of the residents, is listed below the residences, favoring the flow of the effluents to the recharge regions of the spring. These factors constitute a severe problem because, in addition to the high levels of alkalinity and chloride, fecal coliforms of Escherichia coli and urea are likely to be contaminated, as mentioned by Amaral et al. (2003).

Regarding the iron content, the standards of potability require that the water of human supply does not exceed $0.3 \mathrm{mg} . \mathrm{L}^{-1}$ of iron. The iron, although not present toxicity, brings with it numerous problems due to confer the water flavoring, causing stains in clothes and sanitary ware. In addition, according to the Environmental Company of the State of São Paulo (CETESB, 2012), iron causes water turbidity. Another problem is that iron, according to Borda and Branco Jr (2013), promotes the development of ironbacteria in the pipes, causing a marked biological contamination. In addition, turbidity, once above the limits established by this Ordinance, may, according to Mandena (2003) and Daneluz and Tessaro (2015), promote openness to the presence of pathogens, such as oocysts of Cryptosporidium, which, according to the author, the greater the turbidity of the water, the greater the possibility of finding the parasite. In this sense, no sample of water from this study falls under the iron limit defined by Ordinance $2914 / 2011$ and, therefore, inadequate to human use.

The parameters nitrites, nitrates and ammoniacal nitrogen are important for controlling and determining the state and quality of water (DI BLASI et al., 2013). In this sense, according to the Potability Ordinance 2914, the maximum permitted levels for nitrite, nitrate and ammoniacal nitrogen are respectively: $1 \mathrm{mg} . \mathrm{L}^{-1}, 10$ mg. L-1 and 1.5 mg.L-1. In relation to the ammoniacal nitrogen content, both samples showed no ammoniacal nitrogen content in amide $\left(\mathrm{NH}^{2-}\right)$, ammonium $\left(\mathrm{NH}^{4+}\right)$ and ammonia $\left(\mathrm{NH}_{3}\right)$ ions in any of the samples. This result is good both from the point of view of compliance with Ordinance $2914 / 2011$, and also, according to Esteves (1998), because the concentrations of ammoniacal nitrogen directly influence the dynamics of the dissolved oxygen in the water and, consequently, affects the ecological relations present in that aquatic body. In relation to nitrite and nitrate, the samples presented high values of these parameters, dissuading the limit established by the Potability Ordinance 2914/2011 (BRAZIL, 2011). This factor is a major problem, since the intake of nitrates and nitrites for a long time causes a series of dysfunctions to the health of the people and, in high concentrations, can cause methemoglobinemia, disease characterized by the substitution of the oxygen by the $\mathrm{NO}_{2}$ in the blood hemoglobin (CETESB, 2009). In addition to this, high levels of nitrate indicate that there may have been recent water contamination of the two wells.

\section{CONCLUSIONS}

Finally, this study concludes that from the results of the physicalchemical parameters of sample A and sample B that the water from the wells is inappropriate for human consumption. This conclusion is essentially based on the results of the attributes chlorides, conductivity, total dissolved solids, dissolved oxygen and nitrogenous compounds, mainly focused on nitrites and nitrates. The presence of iron should also be taken into account as well as the total hardness, since it may hamper the interaction of soaps to water. All these parameters dissuaded from the Potability Ordinance $2914 / 2011$, ruled by the Ministry of Health. 


\section{REFERENCES}

ALSUHAIMI, A.O.; ALMOHAIMIDI, K.M.; MOMANI, K.A. Preliminary assessment for physicochemical quality parameters of groundwater in Oqdus Area, Saudi Arabia. Journal of the Saudi Society of Agricultural Sciences, 2017.

ALVES, I. C. C.; EI-ROBRINI, M.; SANTOS, M. L. S.; MONTEIRO, S. M.; BARBOSA, L. P. F.; GUIMARÃES, J. T. F. Qualidade das águas superficiais e avaliação do estado trófico do Rio Arari (Ilha de Marajó, norte do Brasil). Acta Amazonica, v. 42, n.1, p. 115$124,2012$.

AMARAL, L.A.; NADER FILHO, A.; ROSSI JUNIOR, O.D.; FERREIRA, F.L.A.; BARROS L.S.S. Água de consumo humano como fator de risco à saúde em propriedades rurais. Revista de Saúde Pública, v.37, n.4, p.510-514, 2003.

AMERICAN PUBLIC HEALTH ASSOCIATION (APHA). Standard Methods of the Examination of Water and Wastewater. USA: Washingtown, 2005.

BARCELLOS, C.M.; ROCHA, M.; RODRIGUES, L.S.; COSTA, C.C.; OLIVEIRA, P.R.; SILVA, I.J.; Jesus EFM; ROLIM, R.G. Avaliação da qualidade da água e percepção hidrogênica- sanitária na área rural de Lavras, Minas Gerais, Brasil 1999-2000. Caderno de Saúde Pública, v. 22, n. 9, p. 1967 - 1978, 2006.

BORDA, A. A.; BRANCO JR, A.C. Perfil físico-químico, microbiológico e ecológico de mananciais d'água na área urbana do município de Ipaussu, São Paulo. In: CONGRESSO BRASILEIRO DE GESTÃO AMBIENTAL, 4., 2013. Anais... Salvador/BA, 25 a 28 de novembro de 2013.

BRAZIL. Lei $N^{\circ}$ 9.433, de 8 de janeiro de 1997. Institui a Política Nacional de Recursos Hídricos, cria o Sistema Nacional de Gerenciamento de Recursos Hídricos, regulamenta o inciso XIX do art. 21 da Constituição Federal, e altera o art. $1^{\circ}$ da Lei $n^{\circ} 8.001$, de 13 de março de 1990, que modificou a Lei $n^{\circ} 7.990$, de 28 de dezembro de 1989. 1997. Disponível em: <http://www.planalto.gov.br/ccivil_03/leis/L9433.htm>. Acesso em: 29 de maio de 2017.

RESOLUÇÃO CONAMA N³57, de 17 de março de 2005. Dispõe sobre a classificação dos corpos de água e diretrizes ambientais para o seu enquadramento, bem como estabelece as condições e padrões de lançamento de efluentes, e dá outras providências. 2005.2 Disponivel em: <http://www.mma.gov.br/port/co-

nama/res/res05/res35705.pdf>. Acesso em: 2 de maio de 2017.

Ministério da Saúde. Portaria de Potabilidade $N^{\circ} 2914$, de 12 de dezembro de 2011. Dispõe sobre os procedimentos de controle e de vigilância da qualidade da água para consumo humano e seu padrão de potabilidade. 2011. Disponível em: $<$ http://site.sabesp.com.br/uploads/file/asabesp_doctos/kit_arsesp_portaria2914.pdf $>$. Acesso em: 2 de maio de 2017.

BUCCI, M. M. H. S.; DELGADO, F. E. F.; SANTOS, D.S.; OLIVEIRA, L. F C. Análise de metais, agrotóxicos, parâmetros físico-químicos e microbiológicos nas águas da Represa Dr. João Penido, Juiz de Fora, MG. Revista Ambiente \& Água, v. 10, n. 4, p. 804-824, 2015.

CAPP, N.; AYACH, L.R.; SANTOS, T.M.B.; GUIMARÃES, S.T.L. Qualidade da água e fatores de contaminação de poçosrasos na área urbana de Anastácio (MS). Geografia Ensino \& Pesquisa, v.16, n. 3, p.77-91, 2012.
COMPANHIA AMBIENTAL DO ESTADO DE SÃO PAULO. Qualidade das águas interiores do estado de São Paulo. São Paulo: CETESB, 2009.

COMPANHIA AMBIENTAL DO ESTADO DE SÃO PAULO. Website. 2012. http://www.cetesb.sp.gov.br. Acesso: 20 set. 2012.

DANELUZ, D.; TESSARO, D. Padrão físico-químico e microbiológico da água de nascentes e poços rasos de propriedades rurais da região sudoeste do Paraná.Arq. Inst. Biol., São Paulo, v.82 p. 1-5, 2015.

ESTEVES, F. Fundamentos de limnologia. Rio de Janeiro: Interciência, 1998. 601p.

HIRATA, R.; ZOBY, J. L. G.; OLIVEIRA, F. R. Água subterrânea: reserva estratégica ou emergencial. In: BICUDO, TUNDISI, SCHEUENSTUHL (Org.). Águas do Brasil: análises estratégicas. Cap. IX, p.149-161, 2010.

INSTITUTO BRASILEIRO DE GEOGRAFIA E ESTATÍSTICA. IBGE Cidades: município de Parelhas/RN. Available from: <https://cidades.ibge.gov.br/xtras/perfil.php?lang=\&codmun=2 40890\&search=rio-grande-do-norte $\mid$ parelhas | infograficos:informacoes-completas>. Acess in: 12 de agosto de 2017.

LIBÂNIO, M. Fundamentos de qualidade e tratamento de água.4. ed.Campinas: Editora Átomo, 2016.

MACEDO, J.A.B. Águas \& águas. 2 ed. Belo Horizonte: CRQ-MG, 2004. $977 p$

MEDEMA, G.J.; SCHETS, F.M.; TEUNIS, P.F.M. Sedimentation of free and attached Cryptosporidium oocysts and Giardia cysts in water. Applied and Environmental Microbiology, v.64, p.44604466, 1998.

MENDES, B.; OLIVEIRA, J.F.S. Qualidade da água para consumo humano. Portugal: Lidel, 2004. 617p.

MENEZES, J.P.C.; BERTOSSI, A.P.A.; SANTOS, A.R.; NEVES, M.A. Qualidade da água subterrânea para consumo humano e uso agrícola no suldo estado do Espírito Santo.Revista Eletronica em Gestão, Educação e Tecnologia Ambiental, v. 17, n. 17 p.3318 3326, 2013.

MOURA, C.C.; GASTAMANS, D.; KIANG, C.H.; MODESTO, R.P.; RODRIGUES, P.F.; RUBY, E.C.; BORGES, A.V. Concentrações de nitrato nas águas subterrâneas em áreas rurais do município de São José do Rio Preto (SP). Águas Subterrâneas, v.29, n.3, p. 268-284, 2016.

PACHECO, G.; COSTA, A.B.; SILVEIRA, E.O.;DEPRA, B.; LOBO, E.A. Calibração de um índice de qualidade de águas subterrâneas (iqnas) para a região do vale do rio Pardo, RS, Brasil: nova ferramenta tecnológica para o monitoramento ambiental. Águas Subterrâneas, v.30, n.3, p. 440-454, 2016.

PEREIRA, D. D. Cariris Paraibanos: do sesmarialismo aos assentamentos de reforma agrária. Raízes da desertificação. 2008. 341f. Tese (doutorado), Universidade Federal de Campina Grande, Campina Grande, PB, 2008.

PEREIRA, R. S.Identificação e caracterização das fontes de poluição em sistemas hídricos.Revista Eletrônica de Recursos Hídricos, v. 1, n. 1. p. 20-36. 2004.

PIÑEIRO DI BLASI, J. I.; MARTÍNEZ TORRES, J.; GARCÍA NIETO, P. J.; ALONSO FERNÁNDEZ, J. R.; DÍAZ MUÑIZ, C.; TABOADA, J. Analysis and detection of outliers in water quality parameters from 
'different automated monitoring stations in the Miño river basin (NW Spain). Ecological Engineering, v. 60, p. 60-66, 2013.

POHLING, R. Reações químicas na análise de água. Fortaleza: Arte Visual, 2009.

RICHTER, C. A. Água: métodos e tecnologia de tratamento. São Paulo: Edgard Blücher. 2009. 1 ed. 352 p.
UNITED STATES. Environmental Protection Agency - USEPA. Secondary maximum contaminant levels: a strategy for drinking water quality and consumer acceptability. 2015. Disponivel em: http://www.waterrf.org/PublicReportLibrary/4537.pdf. Acesso em: 12 de março de 2017. 